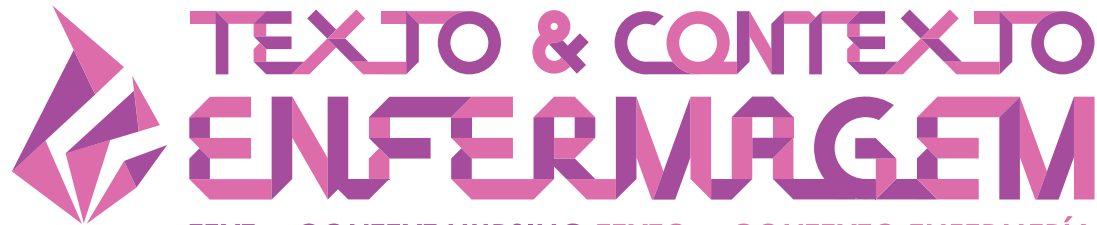

\section{UNVEILING THE STRATEGIES USED BY WOMEN FOR CONFRONTING MARITAL VIOLENCE}

\author{
Jordana Brock Carneiro' ${ }^{1}$ \\ Nadirlene Pereira Gomes ${ }^{1}$ \\ Fernanda Matheus Estrela ${ }^{2}$ (D) \\ Gilvânia Patrícia do Nascimento Paixão ${ }^{3}$ \\ Cátia Maria Costa Romano ${ }^{4}$ \\ Rosana Santos Mota ${ }^{5}$ (1)
}

'Universidade Federal da Bahia, Programa de Pós-Graduação em Enfermagem. Salvador, Bahia, Brasil. ${ }^{2}$ Universidade Estadual de Feira de Santana, Feira de Santana, Bahia, Brasil. ${ }^{3}$ Universidade do Estado da Bahia. Senhor do Bonfim, Bahia, Brasil. ${ }^{4}$ Universidade Federal da Bahia, Escola de Enfermagem. Salvador, Bahia, Brasil. ${ }^{5}$ Complexo Hospitalar Professor Edgard Santos. Salvador, Bahia, Brasil.

\begin{abstract}
Objective: to unveil the strategies used by women for confronting marital violence.

Method: a qualitative research using the Straussian orientation of the Data Grounded Theory as a theoreticalmethodological framework and two Justice Courts for Peace at Home as its scenario. Data was collected through individual interviews and analyzed in the coding process in three interdependent stages: open, axial and selective coding.

Results: to elucidate the "Strategy" component, the following categories emerged: Finding support in family; Being part of groups of women in situations of violence; and Experiencing legal-police support.

Conclusion: given the difficulty women find in breaking with a relationship permeated by violence, it is urgent that the professionals in various areas of care for women be prepared not only to recognize the problem but also to guide them as to the prominence of these resources for exiting from violence situation process and perhaps enable access to these one.
\end{abstract}

DESCRIPTORS: Violence against women. Strategies. Nursing. Family. Grounded theory. 


\section{DESVELANDO AS ESTRATÉGIAS DE ENFRENTAMENTO DA VIOLÊNCIA CONJUGAL UTILIZADAS POR MULHERES}

\section{RESUMO}

Objetivo: desvelar as estratégias de enfrentamento da violência conjugal utilizadas por mulheres.

Método: pesquisa qualitativa que se utilizou da vertente Straussiana da Teoria Fundamentada nos Dados como referencial teórico-metodológico e que teve como cenário duas Varas de Justiça pela Paz em Casa. Os dados foram coletados por meio de entrevistas individuais e analisados no processo de codificação em três etapas interdependentes: codificação aberta, axial e seletiva.

Resultados: para a elucidação do componente "Estratégia", emergiram as seguintes categorias: Encontrando apoio na família; Inserindo-se em grupos de mulheres em situação de violência; e Experienciando o suporte jurídico-policial.

Conclusão: diante da dificuldade feminina em romper com a relação permeada pela violência, urge que os profissionais das diversas áreas de atendimento a mulheres estejam preparados não apenas para reconhecer o agravo como também para orientá-las quanto à saliência desses recursos para o processo de saída desta situação e quiçá viabilizar o acesso a estes.

DESCRITORES: Violência contra a Mulher. Estratégias. Enfermagem. Família. Teoria Fundamentada.

\section{REVELAR LAS ESTRATEGIAS QUE UTILIZAN LAS MUJERES PARA ENFRENTAR LA VIOLENCIA CONYUGAL}

\section{RESUMEN}

Objetivo: revelar las estrategias que utilizan las mujeres para hacer frente a la violencia conyugal.

Método: investigación cualitativa en la que se utilizó la vertiente Straussiana de la Teoría Fundamentada en los Datos como referencial teórico-metodológico y que tuvo escenario dos Tribunales de Justicia para la Paz en el Hogar. Los datos se recolectaron por medio de entrevistas individuales y se los analizó en el proceso de codificación en tres etapas independientes: codificación abierta, axial y selectiva.

Resultados: para elucidar el componente "Estrategia", surgieron las siguientes categorías: Encontrar apoyo en la familia; Integrarse a grupos de mujeres en situación de violencia y Recurrir al apoyo jurídico-policial.

Conclusión: frente a la dificultad que tienen las mujeres en salir de una relación permeada por la violencia, urge que los profesionales de las diversas áreas de atención a las mujeres estén preparados no solo para reconocer la agresión sino también para orientarlas en cuanto a la prominencia de esos recursos para el proceso de salir de esa situación y, quizás, viabilizarles el acceso a dichos recursos.

DESCRIPTORES: Violencia contra la mujer. Estrategias. Enfermería. Familia. Teoría Fundamentada. 


\section{INTRODUCTION}

In weighing the serious repercussions for women's health that interfere with the high rates of morbidity and mortality, marital violence is expressed in a cyclical and lasting way. Facing this juncture, strategies for confronting the phenomenon are necessary.

Women around the world are susceptible to violence, with domestic abuse being more frequent, especially by spouses. In Brazil, a survey of 1,102 women reveals that approximately one in five Brazilian women has experienced some type of domestic or family violence, most often committed by their spouse. ${ }^{1}$ Even in developed countries such as USA, England and Wales, the numbers of marital violence are high, demonstrating the indistinct way in which such violence spreads worldwide. ${ }^{2-3}$

In addition to violence in conjugality rates, it is also important to point out its repercussions for women's lives, with feminicide being its maximum expression. A study in Turkey found that over $70 \%$ of the analyzed femicides occurred at the victim's home. ${ }^{4}$ When not taking their lives, experiencing violence leaves marks on women, such as hematomas, lacerations, bruises and fractures caused by physical aggression and/or due to somatization process. In addition to these, there are mental and physical signs and symptoms of emotional origin, such as insomnia, low self-esteem, panic disorder, gastric ulcers and hypertension. . $^{5-6}$

Female illness results from a context of violence experienced in a lasting and cyclical way throughout the intimate relationship. National and international studies indicate, respectively, a mean time of living together 7 to 10 years. ${ }^{7-8}$ Permanence in violent relationship lasts for long periods precisely because of the cyclical way in which it is experienced by women, signaled by their difficulty in getting out of their situation. ${ }^{9}$ Such cyclicality is usually subtly announced, expressed by psychological violence, and intensified until it culminates in a more serious event, which is usually manifested by the use of physical force. ${ }^{8,10}$ Even after these acute episodes, it is common for women, through the demonstration of the aggressor's regret, forgiveness to their spouses and relationship resumption, known as the honeymoon. ${ }^{11}$

A study conducted in Sweden reveals that Primary Health Care (PHC) nurses realize the limitations of women in breaking up violent relationships. ${ }^{12}$ Considering long years of permanence in marital relationship permeated by violence and the difficulties in getting out of this harmful cycle to their physical and mental health, the following was delineated as the research question: what resources favor women to cope with marital violence? The objective was to unveil the strategies used by women to cope with marital violence.

\section{METHOD}

A qualitative research using the Straussian orientation from the Data Grounded Theory (DGT) as a theoretical-methodological framework. Through people's actions and interactions in a given context and following a rigorous coding system, the DGT allows the researcher to develop and relate concepts, favoring a greater understanding of the phenomenon studied. ${ }^{13}$

As a scenario, the study had two Justice Courts for Peace at Home located in a Brazilian state capital. Data was collected through individual interviews, guided by a form prepared by the researchers. The interviews were previously scheduled by phone and held at the participants' place of choice. The statements were recorded with a portable recorder aid, fully transcribed, and their data were encoded with the support of the NVIVO $10^{\circledR}$ organizer software.

Given the DGT's assumptions, the participants' insertion respected the principles of theoretical sampling. Thus, the first sample group consisted of 29 women, intentionally chosen and meeting the following inclusion criteria: being in court for marital violence with the Justice Courts for Peace at Home. Women whose emotional and psychological status made their participation contraindicated 
by Court's psychosocial service were excluded. Due to the specificity of the "violence in the marital relationship" theme, reflection women's groups were developed as strategies to establish a relationship of trust with the participants in this sample group. The guiding question for this group was: "What resources can you count on to confront marital violence?" Based on their answers, new questions emerged, starting a conversation that aimed to reach data depth on its properties and dimensions and advancement of the research.

In the process of collecting and comparing data for the first sample group, the following hypothesis was formulated: women facing the experience of marital violence seek the support of professionals who work in institutions that care for women in violence situations. This hypothesis directed the continuity of data collection for the second sample group, made up of nine professionals working in these services and referred by women in the first group. The following inclusion criterion was respected: professionals who work in services of the care network for women in situations of violence, by means of interviews with a psychologist, a social worker, a prosecutor, two conciliators, two public defenders and two judges. The professionals who were away from work activities during the interview period were excluded, totaling nine professionals, all women. The uniformity in the composition of this second sample group in relation to gender resulted from the characteristics of the universe that tends to be feminized in this professional area, and is not intentional. The opening of the dialog for this group occurred from the following guiding question: with what resources can women count on to confront marital violence?

To preserve anonymity, the interviewees were identified by the letters $M$ and $P$, respectively, followed by an Arabic numeral from the interview order. In the case of women, it was also decided to enter their ages.

As recommended by the method, data was collected and analyzed concurrently, and the coding process took place in three interdependent stages: open, axial and selective. ${ }^{13}$ In the open coding, the concepts were identified, grouping them into categories according to their similarities. In the axial coding, the categories and subcategories were related for reaching a deeper explanation of the data. This was through an analytical process guided by the paradigmatic model made up by the components of the Straussian orientation: context, causal condition, intervening condition, strategy and consequence. In the last stage, called selective coding, relationships and interactions between the categories were interconnected around a central category, which revealed the phenomenon of experiencing marital violence as a progressive and cyclical process and its repercussions for health and human development. Due to relevance of the "strategies" component, it was decided to deepen its discussion in this study, considering that its understanding may support the planning of actions aimed at addressing this problem.

\section{RESULTS}

To elucidate the "Strategy" component, the following categories emerged: Finding support in the family; Experiencing legal and police support; and Being part of groups of women in situations of violence. These categories emerged from the interviewees' reports, thus portraying the means that supported them in confronting violence in marital relationship.

\section{Finding family support}

The data reveal the importance of family, emotional and/or financial support for the female decision to break the relationship permeated by violence. Lack of support from the family members, in turn, intervenes for permanence and even return to the abusive relationship. 
While he [husband] didn't leave home, I stayed at my son's or my sisters' house. [...] they helped me a lot. I am very dear to my family. (M3, 71 years old)

When I decided to leave home, I had nothing, but I had the support of my family. [...] I stayed at my mother's house. [...] she gave me affection, took care of me and helped me with money until I could stabilize myself. (M1, 29 years old)

Emotional and financial support from the family is critical to support the woman who decides to report violence. [...] without such support, women will often take longer to leave the relationship or end up returning to the violent relationship. (P1)

\section{Experiencing police-legal support}

Resolute police and legal assistance through protective measures, from Ronda Maria da Penha and from the psychosocial service, was pointed as a support that favors breaking the cycle of violence. The understanding of the inquiry-process-sentence flow was also mentioned, which is an important resource for women not to give up the complaint during the legal-police course.

At the police station, they sent me to the Public Prosecutor. Then I was referred to the public defender and to the Court. [...] with the protective measure, he no longer sought me out. [...] I feel like a free person! (M14, 71 years old)

I talked a lot with the Court's social worker and psychologist and they gave me information, support and referred me to women's group. Today I am strengthened! (M2, 68 years old)

[...] the protective measure is fast. It is good to keep his distance from her. [...] Ronda Maria da Penha accompanies the women to ensure that he does not approach. (P2)

\section{Joining groups of women in situations of violence}

This category evidences the relevance of victims of marital violence being included in groups of women in situations of violence. These spaces were held by the judiciary service and by the Violence, Health and Quality of Life (VID@) group, through the Federal University of the Bahia Nursing School. These are recognized by the interviewees as a space of self-knowledge, care and mutual support from the sharing of their stories, which empowers them in searching for a marriage life free from violence.

In the reflection group, you get to know your own story better. I understand that only I can change mine. [...] I felt cared for and supported. (M4, 32 years old)

Attending the prosecution women's group meetings was wonderful! It helped me a lot: I learned that I should change, not try to change my husband. From that, I had the strength to divorce him. (M5, 57 years old)

I can see how participating in groups helps women empower themselves and break out of a violent relationship. (P6)

\section{DISCUSSION}

The study points out that, for long years, some women experience a conjugality permeated by violence, and lists resources that favor such confronting, including family support. In this study, it is revealed that mothers, children and siblings welcome the woman into their homes, helping her financially until she can structure herself to follow her life. In addition to financial support, the family members also support her emotionally, since the emotional state is very committed in this process. Being able to count on the family's emotional and/or financial support contributes to the woman empowerment to decide to end the abusive relationship. Several studies agree that family support is essential for the resilience of women experiencing violence, especially because it favors the improvement of their self-esteem and, consequently, empower them to break this cycle. ${ }^{14-15}$ 
The family being a key element for the individuals' protection, ${ }^{16}$ its lack may weaken the woman and even interfere with her emotional health, situations that compromise the process for breaking the cycle. Corroborating this understanding, a study conducted with more than twenty thousand women from nine countries and from different continents, revealed an association between lack of family support and suicide as a way out of marital violence experienced by victims. ${ }^{17} \mathrm{~A}$ survey conducted in southeastern Europe with women experiencing violence reveals that lack of family support increases permanence in violent relationships and the recurrence rates of new complaints. ${ }^{18}$ This is often due to the family members' belief that marriage is an inseparable bond and should therefore last forever, which contributes to women remaining in the marital relationship, even when permeated by violence..$^{19}$

Another resource that assists women in facing marital violence refers to resolute police and legal assistance. However, because the service is a long way and involves different instances, the study points to the risk of abandoning the process, especially because of lack of knowledge about the procedures that need to be followed. In this context, understanding about the legal-police flow is essential for women not to give up the process, so that proper guidance provided by professionals working in the services that constitute the network of women in situations of violence is indispensable so that they follow up legal action.

This service network is made up of health services, social and legal-police assistance, based on the National Plan of Policies for Women, which guides to a set of public policies and services aimed at promoting rights and at guaranteeing assistance for women victimized by violence. It is noteworthy that, by acting in a network, the sectors involved must have their actions thought out in an integrated and articulated manner, thus enabling the expansion of the assistance provided and the provision of better quality services that allow identification of violence, care and referrals, ${ }^{20-21}$ ensuring a resolute attention to women's needs.

It is noteworthy that in order to register an occurrence, in general, the first step is to go to the police station, which can be the specialized one (Women's Police Station - Delegacia de Atendimento à Mulher, DEAM), the one for the elderly (when it is a woman aged 60 years old or more) or even a common police station. From the police station, the police inquiry goes to the Public Prosecution Service, which decides whether to report the complaint. If so, the process is set up and sent to the Violence Court, where the causes of a civil nature (protective measures, for example) and the criminal (of the act itself) arising from domestic and family violence against woman are judged and executed. ${ }^{22}$ Women need to understand that the registration of the incident in the police station is only the initial "kick", and, therefore, the sequencing of other legal actions necessary to forward the complaint to the protective measures. This understanding is fundamental for preventing women from giving up living a life free of violence.

Still regarding the legal-police support, the participants allude to the protective measures, which are set out in Chapter II of Law No.11,340, of August $7^{\text {th }}, 2006$. They are set up as instruments used to preserve the victim's and the children's fundamental rights, when necessary, being issued by a judge within 48 hours of the request of the Public Prosecution Service, or at the request of the offended, and may be isolated or cumulative. ${ }^{22-23}$ Among the most applicable measures are removal from home or other place of living; setting a minimum limit between the parties; and suspension of visits to minor children, in case of risk for them also. The measure may also seek to protect the property of the woman's individual property, as well as those of the marital society, temporarily preventing the conclusion of acts and contracts of purchase, sale and rental of common property. It is to be noted that the protective measure may be suspended if the woman wishes so. ${ }^{22}$

It is noteworthy that the protective measure has civil character as its legal nature, not criminal, since it is a means aimed at protecting the victim, preventing the continuation of the aggressions, and not necessarily impose a sanction to the offender. However, when there is non-compliance with 
the provided measures, the judiciary service may order the preventive arrest and institute criminal proceedings, turning the situation into one of criminal nature so that the victim is protected in accordance with Article 313 of the Code of Criminal Procedure. ${ }^{22}$ Importantly, non-compliance with the protective measure does not constitute a crime of disobedience because this only occurs when there is no legal provision of a specific sanction and, in this case, the Maria da Penha Law already provides extrapenal measures for this occurrence, namely: preventive detention. ${ }^{24}$

For the effectiveness of the protective measures to be achieved, it is necessary that protection and care programs for women are in regular operation. ${ }^{23}$ In some states of Brazil, the Ronda Maria da Penha has been instituted, a 24-hour action linked to the Military Police so that the followed-up women call when there are problems related to non-compliance with the protective measure. ${ }^{25}$ The main objective of the Ronda is to monitor victims of violence to ensure that the protective measures are respected, including the imprisonment of the man who disrespects them and the referral of the woman to report a new occurrence, if applicable.

In addition to the dismissal actions of perpetrators of violence, it is important to highlight the care of victims by the multidisciplinary care team (psychologist and social worker) of the Justice Courts for Peace at Home. Among this team's duties is the provision of written grants to the judge, prosecutor and public defender, in contact with involved parties in the investigation, to be used in hearings. This team also develops orientation, referral, prevention and other measures aimed at women, men and their families, with special attention to children and adolescents. ${ }^{23}$

Similarly, the Center for the Defense of Women's Rights (Núcleo de Defesa dos Direitos da Mulher, NUDEM) is linked to the Public Defender's Office and is of great importance as it is a space for legal assistance to women in situations of violence. It is responsible for providing legal advice and for the defense in court, in all levels, of low-income citizens, and this organ is also inserted in the Courts and Judgeships. ${ }^{26}$ In addition, groups of women are held for empowerment and female reflection, in which they can speak, are heard and realize that violence is not a one-off problem, which increases their self-esteem and strengthens them to decide for their own change.

The groups of women in situations of marital violence were also mentioned by the participant of this study as a strategic resource to confront this type of violence, whether promoted by the judiciary instance or organized in partnerships with higher education institutions. Such spaces favor reflection and female empowerment, as in the reflection group in which this research interviewees were integrated, considering it as a positive resource of support, care and self-knowledge, because it enables women to express feelings, share experiences, reflect on behaviors and (re)think attitudes, especially in the sense of transforming oneself, not projecting change in the other. Aiming to provide such reflections for the other subject of the relationship, the Maria da Penha Law provides for the creation of programs for the recovery and re-education of men. ${ }^{23}$ These can be developed in partnership with social, health and education services, such as the reflection group mentioned by interviewees, which is under the coordination of a northeastern university. It is important to mention that, although the participants are referred by the Violence Court, most groups, as well as the reflection group in question, do not suffer interference from this organ, and vice versa.

Corroborating the prominence of family and institutional support, which includes the groups with women, international studies conducted in Sweden and the USA warn of the importance that professionals working in PHC be able to make the referrals to the women in situations of violence. These should also lead groups not only of women, but also of men, focusing on gender reflection and empowerment based on community interventions to break out of abusive relationships. ${ }^{12,27}$ Professional training is essential in order to promote care for women who experience a marital daily life permeated by violence, as indicated by a national research conducted in Santa Catarina with Family Health Strategy (FHS) doctors and nurses. These refer to the unpreparedness in how to act 
in this context, signaling the need for a management that prioritizes this problem recognition and a qualified attention to these women, which involves, among other issues, knowledge about the resources of empowerment. ${ }^{28}$

The findings indicate the relevance of the professionals creating strategies for strengthening and/or reestablishing the family bond. These can be, for example, from encouraging women to resort to the family members or through educational actions with the family members to understand their importance for strengthening women in the decision-making process. Another limitation refers to the lack of deepening of in which point in life women sought these resources. Thus, further research is needed to broaden the understanding of the life-experienced context by women when looking for different forms of support to break the scenario of marital violence.

\section{CONCLUSION}

The study revealed that, in view of the situation of marital violence experienced by women, family support, police-legal support and participation in groups of women who experience this situation constitute resources that offer subsidies to confront the phenomenon. Facing the difficulty women have to break with the relationship permeated by violence, it is urgent that the professionals from the different areas of care for women be prepared not only to recognize the problem, but also to guide them as to the prominence of these resources for the process to exit this situation and perhaps, enable access to these resources.

In the health field, such actions can and should be conducted by nurses since, given their greater proximity to the community, they are in a prominent position to establish an interaction, especially in $\mathrm{PHC}$, where they usually occupy coordination positions and/or join the reference team. From the home visits and educational actions, this context enables the approximation between health professionals and women/family members and the consequent availability of guidance and care, aiming at female empowerment for a life free of violence. Still with regard to the educational measures, it is important to highlight the organization and conduct of women's groups, essential for the process of deconstruction of gender inequality that sustains marital violence.

\section{REFERENCES}

1. Brasil. Secretaria de Transparência. Violência doméstica e familiar contra a mulher. Brasília, DF(BR): Senado Federal; [Internet] 2015 [cited 2019 Dec 07]. Available from: https://www12. senado.leg.br/institucional/datasenado/pdf/Relatrio_Violncia_Mulher_v9formatado.pdf

2. Hutt J. Letter from Minister for Finance and Government Business to the Chair of Finance Com. Llywodraeth Cymru Welsh Government; [Internet] 2016 [cited 2019 Dec 07]. Available from: http://senedd.assembly.wales/documents/s49856/Letter/from/the/Minister/for/Finance/and/ Government/Business/to/the/Chair/of/the/Finance/Committee/-.pdf

3. National Center for Injury Prevention and Control. Preventing Intimate Partner Violence [Internet] 2017 [cited 2018 Aug 4]. Available from: https://www.cdc.gov/violenceprevention/pdf/ipvtechnicalpackages.pdf

4. Toprak S, Ersoy G. Femicide in Turkey between 2000 and 2010. Stöckl H, editor. PLoS One [Internet]. 2017 [cited 2018 Oct 03];12(8):e0182409. Available from: https://dx.doi.org/10.1371/ journal.pone.0182409

5. Acosta DF, Gomes VLO, Fonseca AD, Gomes GC. Violence against women commited by intimate partners: (in)visibility of the problem. Texto Contexto Enferm [Internet]. 2015 [cited 2018 Oct 03];24(1):121-7. Available from: https://dx.doi.org/10.1590/0104-0707201500170013 
6. Kapiga S, Harvey S, Muhammad AK, Stöckl H, Mshana G, Hashim R, et al. Prevalence of intimate partner violence and abuse and associated factors among women enrolled into a cluster randomised trial in northwestern Tanzania. BMC Public Health [Internet]. 2017 [cited 2018 June 4];17(1):190. Available from: https://dx.doi.org/10.1186/s12889-017-4119-9

7. Estrela FM, Gomes NP, Lírio JGS, Silva AF, Mota RS, Pereira Á, et al. Expressions and repercussions of conjugal violence: processes of women in a probate court. Rev enferm UFPE [Internet]. 2018 [cited 2018 Oct 3];12(9):2418-27. Available from: https://dx.doi.org/10.5205/19818963-v12i9a231013p2418-2427-2018

8. Hajian S, Vakilian K, Mirzaii Najm-abadi K, Hajian P, Jalalian M. Violence against Women by Their Intimate Partners in Shahroud in Northeastern Region of Iran. Glob J Health Sci [Internet]. 2014 [cited 2018 Oct 3];6(3):117-30. Available from: https://dx.doi.org/10.5539/gjhs.v6n3p117

9. Razera J, Falcke D. Por que eles permanecem juntos? Contribuições para a permanência em relacionamentos íntimos com violência. Psicol Clínica [Internet]. 2017 [cited 2018 Oct 3];29(3):543-62. Available from: http://pepsic.bvsalud.org/scielo.php?script=sci_ arttext\&pid=S0103-56652017000300010

10. Huecker MR, Smock W. Domestic Violence. [Internet]. Treasure Island, FL(US): StatPearls StatPearls Publishing; 2018 [cited 2018 Oct 3]. Available from: http://www.ncbi.nlm.nih.gov/ pubmed/29763066

11. Silva FP, Oliveira FAP, Varela S, Batista RA, Barbosa LR. The biopsychosocial sphere of women victims of violence: a systematic review. Aquichan [Internet]. 2017 [cited 2018 Oct 3];17(4):390400. Available from: https://dx.doi.org/10.5294/aqui.2017.17.4.3

12. Sundborg E, Törnkvist L, Wändell $P$, Saleh-Stattin N. Impact of an educational intervention for district nurses about preparedness to encounter women exposed to intimate partner violence. Scand J Caring Sci [Internet]. 2018 [cited 2018 Oct 3];32(2):902-13. Available from: http://dx.doi. org/10.1111/scs. 12521

13. Strauus A, Corbin J. Pesquisa qualitativa: técnicas e procedimentos para o desenvolvimento de teoria fundamentada. 2th ed. Porto Alegre, RS(BR): Artmed; 2008.

14. Gomes NP, Erdmann AL, Gomes NR, Monteiro D da S, Santos RM, Couto TM. Social support to women in situation of domestic violence. Rev Salud Publica (Bogota) [Internet]. 2015 [cited 2018 Oct 3];17(6):823-35. Available from: https://dx.doi.org/10.15446/rsap.v17n6.36022

15. Carneiro JB, Gomes NP, Estrela FM, Santana JD de, Mota RS, Erdmann AL. Domestic violence: repercussions for women and children. Esc Anna Nery [Internet]. 2017 [cited 2018 Oct 3];21(4):e20160346. Available from: https://dx.doi.org/10.1590/2177-9465-ean-2016-0346

16. Oyesanya TO, Bowers B. "I'm trying to be the safety net": family protection of patients with moderate-to-severe TBI during the hospital stay. Qual Health Res [Internet]. 2017[cited 2018 Oct 10]; 27(12):1804-15. Available from: https://dx.doi.org/10.1177/104973231769709

17. Albuquerque Netto L, Moura MAV, Araujo CLF, Souza MHN, Silva GF. Social support networks for women in situations of violence by an intimate partner. Texto Contexto Enferm [Internet]. 2017 [cited 2018 Oct 3];26(2):e07120015. Available from: https://dx.doi.org/10.1590/010407072017007120015

18. Kelmendi K. Domestic Violence Against Women in Kosovo. J Interpers Violence [Internet]. 2015 [cited 2018 Oct 3];30(4):680-702. Available from: https://dx.doi.org/10.1177/0886260514535255

19. Cabrera O. Gênero, sexo e raça e a formação de subjetividades femininas em Cuba, século XIX. Rev Estud Fem [Internet]. 2017 [cited 2018 Oct 3];25(1):117-45. Available from: https://dx.doi. org/10.1590/1806-9584.2017v25n1p117 
20. Tojal AL, Silva QMF, Almeida ACMS, Roza TFSM.Rede de enfrentamento à violência contra a mulher: situação dos serviços especializados no município de Maceió. Rev Bras Técn Sociais. [Internet] 2016 [cited 2018 Oct 3];3(2):22. Available from: https://dx.doi.org/10.14210/rbts.v3.n1. p13-22

21. Brasil. Plano Nacional de Políticas para as Mulheres. [Internet]. Brasília, DF(BR): Secretaria de Políticas para as Mulheres; 2013 [cited 2018 Oct 3]. Available from: http://www.spm.gov.br/ assuntos/pnpm/publicacoes/pnpm-2013-2015-em-22ago13.pdf

22. Silva AS, Barbosa GSS. Política criminal e Lei Maria da Penha: o deferimento do comparecimento do agressor a programas de recuperação e reeducação como a principal medida protetiva de urgência. Rev Criminol Polit Criminais [Internet]. 2017 June[cited 2018 Oct 3];3(1):78. Available from: https://dx.doi.org/10.26668/IndexLawJournals/2526-0065/2017.v3i1.1799

23. Brasil. Lei n. 11.340, de 7 de Agosto de 2006:Cria mecanismos para coibir a violência doméstica e familiar contra a mulher, nos termos do $\S 8^{\circ}$ do art. 226 da Constituição Federal, da Convenção sobre a Eliminação de Todas as Formas de Discriminação contra as Mulheres e da Convenção Interamericana para Prevenir, Punir e Erradicar a Violência contra a Mulher; dispõe sobre a criação dos Juizados de Violência Doméstica e Familiar contra a Mulher; altera o Código de Processo Penal, o Código Penal e a Lei de Execução Penal; e dá outras providências. Brasília, DF(BR): Diário Oficial da União; 7 de agosto de 2006.

24. Weingartner $\mathrm{J}$ Neto. A efetividade de medida protetiva de urgência no âmbito da violência doméstica e familiar: o crime de desobediência. Direito \& Justiça [Internet]. 2014 May 19 [cited 2018 Oct 3]; 40(2):144. Available from: https://dx.doi.org/10.15448/1984-7718.2014.2.17323

25. Ronda Maria da Penha comemora 12 anos da lei com Workshop [Internet]. A Tarde. 2018 [cited 2018 Oct 3]. Available from: http://atarde.uol.com.br/bahia/salvador/noticias/1983104-rondamaria-da-penha-comemora-12-anos-da-lei-com-workshop

26. Ministério dos Direitos Humanos (BR). Retrospectiva SPM 2015 [Internet]. Brasília, DF(BR): Secretaria de Política Pública para Mulheres; 2015 [citado 2018 Oct 3]. Available from: http:// www.spm.gov.br/restrospectiva-spm-2015

27. Ellsberg M, Arango DJ, Morton M, Gennari F, Kiplesund S, Contreras M, et al. Prevention of violence against women and girls: what does the evidence say? Lancet [Internet]. 2015 [cited 2018 Oct 3];385:1555-66. Available from: https://dx.doi.org/10.1016/S0140-6736(14)61703-7

28. Gomes VR, Lima VLA, Silva AF, Sena LX, Santos ACB. Violência contra a mulher na região norte: a versão da mídia impressa paraense. Rev LEVS [Internet]. 2014 [cited 2017 May 23];14(1):11328. Available from: http://www2.marilia.unesp.br/revistas/index.php/levs/article/view/4213/3073 


\section{NOTES}

\section{ORIGIN OF THE ARTICLE}

The study is linked to the matrix reasearch entitled "Re-educating men and women involved in a criminal process: the strategy to face marital violence", developed by the Violence, Health an Quality of Life Research (VID@) Group of the Universidade Federal da Bahia.

\section{CONTRIBUTION OF AUTHORITY}

Study Desing: Carneiro JB, Estrela FM, Gomes NP.

Data collection: Carneiro JB, Paixão GPN, Mota RS.

Analysis and interpretation of data: Carneiro JB, Gomes NP, Mota RS.

Discussion of the results: Carneiro JB, Estrela FM, Gomes NP, Romano CMC, Paixão GPN.

Writing and/or critical review of content: Carneiro JB, Romano CMC, Mota RS.

Review and final approval of the final version: Carneiro JB, Estrela FM, Gomes NP.

\section{FINANCING INFORMATION}

Fundação de Amparo à Pesquisa no Estado da Bahia, - FAPESB and Secretaria de Segurança Pública da Bahia, for granting the funding for the development of the project.

\section{APPROVAL OF RESEARCH ETHICS COMMITTEE}

Approved by the Ethics Committee in Research with Human Beings of the School of the Universidade Federal da Bahia No.877,905/2014; CAAE 31286414.2.0000.5531.

\section{CONFLICT OF INTERESTS}

There is no conflict of interest.

\section{HISTORICAL}

Received: November 13, 2018

Approved: March 01, 2019

\section{CORRESPONDENCE AUTHOR}

Fernanda Matheus Estrela

nanmatheus@yahoo.com.br 